\title{
Rhinoceroses from the paleontological collection of the Zaporozhye Regional Museum of Local History (Ukraine): SYSTEMATIC AND ECOLOGICAL DIVERSITY
}

\author{
Krakhmalnaya T.V. ${ }^{1}$, Kovalchuk O.M. ${ }^{1}$, Derkach T.G. ${ }^{2}$ \\ ${ }^{1}$ National Museum of Natural History of the National Academy of Sciences \\ of Ukraine, Kiev, Ukraine, tvkrakhmalnaya@gmail.com, biologiest@ukr.net \\ 'Zaporozhye Regional Museum of Local History, Zaporozhye, Ukraine
}

https://doi.org/10.53937/9789975315975.13

\begin{abstract}
The results of determination of fossil remains of rhinoceroses from the Zaporozhye regional museum of local history are presented in the paper. It is established the presence of at least five species belonging to three subfamilies (Aceratheriinae, Dicerorhininae, Elasmotheriinae) within Rhinocerotidae. These fossils were collected in different parts of the Zaporozhye region and dated back in the wide range of late Miocene - late Pleistocene. Rhinos' remains are represented by isolated teeth, mandibles, as well as postcranial elements (vertebrae, scapula, humerus, tibia, metapodia, and ribs). Paleoecological aspects of these animals are discussed, and importance of further study of such collections is underlined.
\end{abstract}

Key words: Rhinocerotidae, fossils, Miocene, Pliocene, Pleistocene.

\section{INTRODUCTION}

Numerous fossil remains of vertebrates (in particular, large mammals belonging to orders Carnivora, Proboscidea, Perissodactyla, Cetartiodactyla) were found in Miocene-Pleistocene deposits on the territory of Zaporozhye region. These materials are recently deposited in the paleontological collection of the Zaporozhye regional museum of local history (acronym - ZRMLH). Some of them are exhibited, the rest are kept in the museum funds. Proboscideans and ungulates form the basis of museum exhibition in the number of finds and their systematic diversity. Employees of the ZRMLH together with colleagues from the National Academy of Sciences of Ukraine are gradually introducing 
materials from their collections into scientific circulation. In particular, a catalogue of teeth of Pliocene-Pleistocene elephants was prepared and published by Derkach \& Logvinenko [6]. Besides, it should be also noted the publication by Kovalchuk \& Derkach [13] devoted to the description of the fossil fish remains from ZRMLH.

The present paper has been prepared with a view to continuing the description of the fossil remains of large mammals, namely those belonging to the family Rhinocerotidae. Representatives of this group were a characteristic component of ancient faunas and always aroused interest among paleozoologists. Ancient rhinos can also serve as an important indicator for the reconstruction of the environment during their existence. Without focusing on morphological description of the remains of rhinos at the moment, we concentrated our attention on the following issues: systematic diversity, preservation of the material and its anatomical composition, geography and geological age of the fossils. In order to realize these issues, museum catalogues were analyzed, and information from them was compared with original materials. Based on obtained data, ecological and paleogeographic aspects are discussed herein.

History of the study. Bone remains of Rhinocerotidae from ZRMLH were previously studied and determined by I.G. Pidoplichko (Institute of Zoology, Academy of Sciences of the Ukrainian SSR, 1955), V.E. Garutt (Zoological Institute, Academy of Sciences of the USSR, 1959, 1967), V.I. Svistun (Institute of Zoology, Academy of Sciences of the Ukrainian SSR, 1972, 1980), V.I. Zhegallo (Paleontological Institute, Academy of Sciences of the USSR, 1982), V.N. Logvinenko (National Museum of Natural History, National Academy of Sciences of Ukraine, 2007), M.P. Kalmykov (Southern Scientific Center, Russian Academy of Sciences, 2011), and T.V. Krakhmalnaya (National Museum of Natural History, National Academy of Sciences of Ukraine, 2018). I.G. Pidoplichko [16] noted a number of localities with mammalian fossils on the territory of the Zaporozhye region, among which are, for example, Belenkoye, Bolshoy Tokmak, Zaporozhye, 
Melitopol, Fedorovka and Khortitsa. Bones of a woolly rhinoceros were found in Shum on the Dnieper River in 1936. Somewhat later, in 1949, a mandible of Elasmotherium sibiricum was found near Osipenko village (now - Berdyansk), on the shore of the Sea of Azov. The lower jaw of a woolly rhinoceros was extracted from the water on the left bank of the Dnieper River in 1951 (comm. G.I. Moliavko). In 1954, V.A. Topachevsky obtained the skull of elasmotherium from the late Pliocene gravel near the Bolshoy Tokmak. A scapula of this species was found in vicinities of the Bolshaya Znamenka. Radius and calcaneus of elasmotherium comes from the Sea of Azov near Nogaisk [16].

Formation of collection yielding bone remains of ancient rhinos. According to the catalogue of ZRMLH, the earliest post-war finds of rhino's fossils are belonging to the Caucasian elasmotherium. The following specimens were confined to the mid-1950s (1954-1957). The material was transferred to the museum in 1961, 1963, and 1967. The most recent records - teeth of Chilotherium and Coelodonta - dated back to 1972 and 1980.

\section{MATERIAL AND METHODS}

The material under study originates from the Zaporozhye region and is confined to the Vasilievskyi, Krasnoarmeyskyi, Zaporozhskyi and Verkhne-Khortitskyi districts. Mammalian fossils were found on banks of the Dnieper River, as well as the Yanchokrak and Kakhovka reservoirs, in sand quarries near settlements, on the island of Khortitsa. The following localities are indicated in the catalogue of ZRMLH: Zaporozhye, Bolshoy Tokmak, Melitopol, Lysaya Gora, Vasilyevka, Kamenskoe, Novoaleksandrovka, Belenkoye, Fedorovka, Mayachki, Andreevka, Lysogorka, and coast of the Kakhovka water reservoir.

Complete skeletons, skulls or their fragments, as well as anatomical postcranial groups of rhinos are missing in the collection of ZRMLH. Since these were random finds rather than those obtained at purposeful searches for fossils or large-scale excavations, the character of the studied 
material is quite understandable. In total, 27 specimens are available for the study. Among them, isolated teeth (8), mandible fragment (1), thoracic-caudal vertebrae (6), scapula (1), humerus (2), and tibia (1) are represented. There are also metapodia (4) and ribs (2) without indicating a species. Mandible of the woolly rhinoceros Coelodonta antiquitatis and almost complete humerus of Elasmotherium caucasicum are of greatest interest in terms of their preservation.

The system of rhinoceroses (at the subfamily level) follows Dollo [7] for Elasmotherium, Simpson [18] for Stephanorhinus, Deng [4] for Chilotherium, and Guerin [11] for Coelodonta.

\section{RESULTS AND DISCUSSION}

Systematic diversity. Fossil material in ZRMLH, based on current determinations, refers to four genera and three subfamilies within Rhinocerotidae - Aceratheriinae (Chilotherium), Dicerorhininae (Stephanorinus, Coelodonta) and Elasmotheriinae (Elasmotherium). We assume the presence of at least 5 species in this collection: Chilotherium shlosseri (Weber, 1905), ?Stephanorhinus kirchbergensis = "Dicerorhinus merki" (Kaup, 1841), Elasmotherium caucasicum Borissiak, 1914, ?E. peii Chow, 1958, Coelodonta antiquitatis (Blumenbach, 1799).

Taking into account high fragmentation of most of the material, it is difficult to determine its species affiliation, and sometimes also the generic one. With confidence, we can talk about the presence of fossils belonging to representatives of Chilotherium, Elasmotherium and Coelodonta in the collection of ZRMLH. It should be noted that the skull of elasmotherium from Tokmak, defined as Elasmotherium caucasicum [20], is exposed in the National Museum of Natural History NAS of Ukraine (NMNHU-P, Kiev). A.K. Shvyreva [17] classified this specimen as belonging to another species - E. peii described from China. The author refers to the materials stored in the same museum and obtained from the Zaporozhye region: a fragment of the radial bone (NMNHU-P No. 4618) from Berdyansk, the sixth cervical vertebra (NMNHU-P No. 4616) from Mariupol. A.K. Shvyreva defined them as Elasmotherium caucasicum [17]. 
Geological age. Fossil remains of rhinos in the studied region were obtained from upper Miocene-upper Pleistocene deposits. The most ancient representatives of the family on this territory are the hornless rhinoceroses referring to Chilotherium shlosseri. This species lived on the modern territory of Ukraine during late Miocene. Representatives of the genus were common in the Miocene-early Pliocene of Europe, Kazakhstan, Kirghizia and China [8]. The genus Elasmotherium was common in the late Pliocene-middle Pleistocene of Europe, Siberia, Middle Asia, Kazakhstan and China [8]. Elasmotherium caucasicum is recorded for the end of the early Pleistocene of Eurasia [5], and also within the Tamanian faunal complex on the Northern Caucasus and Southern Ukraine [17]. E. peii according to A.K. Shvyreva [17] was distributed in Eurasia during middle Pliocene-early Pleistocene. Stephanorhinus kirchbergensis was common in northern Eurasia during early and middle Pleistocene [8]. The youngest species is Coelodonta antiquitatis, whose range in the middle-late Pleistocene covered the entire northern Eurasia [15]. Recently known remains of this species in Ukraine are confined mainly to the late Pleistocene.

Ecological implications and paleogeographic remarks. Hornless Chilotherium, based on the morphology of its teeth and symphysis of its lower jaw, refers to a highly specialized group of rhinoceroses. This animal ate coastal plants, rhizomes and fruits. Strong shortening of the distal parts of the limbs and barrel-shaped body, apparently, did not contribute this rhino to the long rapid walking. Most likely, it lived in low humid and swampy places $[1,9,12,14]$.

Stephanorhinus can be regarded as a typical inhabitant of the foreststeppe. It is believed that the ancient forms of rhinos, possessing relatively meso-hypsodont teeth and slender limbs, gravitated toward the conditions of the forest-steppe [10,21,22]. Most extant rhinoceroses, being inhabitants of open and semi-open landscapes, prefer to eat shrub shoots and tall grass. 
As for the woolly rhinoceros Coelodonta antiquitatis, it is known that this animal lived in open spaces with extremely cold but dry climate, minimal snow cover (up to 20-25 c), and mainly grassy vegetation [19]. Studies of horn structure of the woolly rhinoceros confirmed its high strength. This animal used its long, flattened nasal horn not only as a protective and "tournament" weapon, but also for raking snow in search of food $[2,3]$.

Elasmotherium, like a woolly rhinoceros, as well as extant white rhinoceros, gravitated towards open habitats. Based on morphofunctional and ecological data, A.K. Shvyreva [17] concluded that representatives of this genus lived in savanna that passed into steppe. It can be assumed from the low-positioned head of this rhino (deflection angle of the occipital bone from the skull base is always greater than the direct one) and its predominant feeding by a low-grass vegetation. The space of trophic resources expanded due to intrazonal near-water plant communities. In arid and cold season, this space was corrected by the extraction of underground parts of plants, as indicated by the structure of skull and teeth of Elasmotherium [17].

\section{CONCLUSIONS}

Fossil materials on large mammals and other groups from regional and urban museums of local history in Ukraine are of great interest to paleozoologists. Their further detailed study is important and promising. In addition to scientific significance, the work of the Zaporozhye regional museum is of great importance for educational and educational activities. This is one of the cultural centers in Southern Ukraine, which carefully stores and replenishes its collections.

The materials presented in the paper contribute to the study of the biodiversity of faunas of past geological epochs within the Zaporozhye region. Analysis of the available osteological material in paleoecological and paleogeographic aspects allows us to assume the development of various morphological adaptations in ancient rhinos according to their environment. 
Woolly rhinoceros and elasmotherium were adapted to feed on grassy vegetation, which they tore right off the ground. Both these forms inhabited open spaces: tundra-steppe in the case of the first species and savannah passing into steppe in the case of the second one. Elasmotherium in certain unfavorable seasons could also extract underground parts of near-water plants. These parts served as the main food for Chilotherium, who preferred low relief areas with soft ground. Stephanorhinus also inhabited the forest-steppe and, in contrast to the rhinos mentioned above, ate sprouts and leaves of shrubs, as well as tall grass.

\section{REFERENCES}

1. Beliaeva E. 1954. New materials on the Tertiary rhinos of Kazakhstan. Tertiary mammals. Publishing House of the Academy of Sciences of the USSR. Moscow, 47(2): 24-54.

1. Boeskorov G.G. 2012. Some specific morphological and ecological features of the fossil woolly rhinoceros (Coelodonta antiquitatis Blum., 1799). Biology Bulletin, 39(8): 692-707.

1. Boeskorov G.G., Bakulina N.T., Davydov S.P., Shchelchkova M.V., Solomonov N.G. 2011. Study of Pollen and Spores from the Stomach of a Fossil Woolly Rhinoceros Found in the Lower Reaches of the Kolyma River. Doklady Biological Sciences, 436: 23-25.

2. Deng T. 2006. A primitive species of Chilotherium (Perissodactyla, Rhinocerotidae) from the Late Miocene of the Linxia basin (Gansu, China). Cainozoic Research, 5: 93-102.

1. Deng T., Zheng M. 2005. Limb bones of Elasmotherium (Rhinocerotidae, Perissodactyla) from Nihewan (Hebei, China). Vertebrata Palasiatica, 43: 110-121.

2. Derkach T.G., Logvinenko V.N. 2007. Catalogue of the teeth of fossil elephantids from the collection of the Zaporozhye regional museum of local history as of 2007. Muzejnyi Visnyk, 7: 162-168 [in Russian].

3. Dollo L. 1885. Rhinocéros vivants et fossiles. Revue des Questions Scientifiques, 17: 293-300.

4. Garutt V.E. 1981. Perissodactyla. In: Gromov I.M. \& Baranova G.I. (eds), Catalogue of the USSR Mammals - Pliocene-Present. Nauka, Leningrad, pp. 336-342 [in Russian]. 
1. Gromova V.I. 1954. Paludal rhinoceroses (Amynodontidae) of Mongolia. Trudy PIN AN SSSR, 55(3): 85-189] [in Russian].

2. Gromova V.I. 1965. A brief overview of Quaternary mammals in Europe (comparison experience). Nauka, Moscow, 143 p. [in Russian].

1. Guérin C. 1980. Les rhinocéros (Mammalia, Perissodactyla) du Miocène terminal au Pléistocène supérieur en Europe occidentale: comparaison avec les espèces actuelles. Documents des Laboratoires de Géologie de Lyon, 79: 1-1184.

2. Korotkevich E.L. 1988. History of the formation of the Hipparion-fauna of East Europe. Naukova Dumka, Kiev, 161 p. [in Russian].

1. Kovalchuk O.M., Derkach T.G. 2014. Fossil fishes in osteological collection of Zaporozhye Local History Museum. Muzejnyi Visnyk, 14: 5-10 [in Russian].

2. Krakhmalnaya T.V. 1996. The Hipparion-fauna of the ancient Maeotian of the North peri-Pontic region. Naukova Dumka, Kiev, 225 p. [in Russian, with English summary].

1. Markova A.K., Smimov N.G., Kozhovinov A.Y., Kazantseva N.E., Simankova A.E., Kitaev A.N. 1995. Late Pleistocene distribution and diversity of Mammals in Northem Eurasia. Paleontologia i Evolucio, 28-29: 5-143.

2. Pidoplichko I.G. 1956. Materials on the study of the fossil fauna of Ukraine, no. 2. Academy of Sciences of the UkrSSR, Kyiv, 235 p. [in Ukrainian].

3. Shvyreva A.K. 2016. Elasmotherium in the Eurasian Pleistocene. Pechatnyi Dvor, Stavropol, 216 p. [in Russian].

1. Simpson G.G. 1945. The principles of classification and a classification of mammals. Bulletin of the American Museum of Natural History, 85: 1-350.

1. Stuart A.J., Lister A.M. 2012. Extinction chronology of the woolly rhinoceros Coelodonta antiquitatis in the context of Late Quaternary megafaunal extinctions in Northern Eurasia. Quaternary Science Reviews, 51: 1-17.

1. Svistun V.I. 1973. Elasmotherium caucasicum Boriss. skull from the late Pliocene deposits in the Zaporozhie region. Vestnik Zoologii, 2: 53-60 [in Russian].

2. Titov V.V. 2008. Late Pliocene large mammals from Northeastern Sea of Azov Region. SSC RAS Publishing, Rostov-on-Don, 264 p. [in Russian].

3. Vekua A.K. 1972. Kvabebi fauna of Akchagylian vertebrates. Nauka, Moscow, 351 p. [in Russian]. 